\title{
SEMANTIC FEATURES OF NOUNS REFERRED TO VARIOUS LEXICAL-AND-GRAMMATICAL CATEGORIES
}

\author{
Vadim A. Belov \\ Cherepovets State University, Cherepovets, Russia
}

\begin{abstract}
The paper focuses on semantic properties of concrete and abstract nouns in the aspect of their cognitive categorization. The research is based on the results of two psycholinguistic experiments carried out by the author: synonym selection and word interpretation. The data obtained are verified by comparing data from the dictionaries of synonyms and National Corpus of the Russian Language. The synonym collection experiment shows that the speakers tend to extend synonymic relations of concrete nouns by means of semantic convergence of the words, which belong to different levels of hierarchy in the semantic field. Special attention is paid to nouns denoting a person. Their synonymic ranges differ significantly in lexicographic sources and the experiment findings. The word interpretation experiment points to the frequency of a logical (componential) method for interpretation of concrete nouns meaning, and synonymic method for abstract nouns. Concrete nouns are noted to realize logical categorization due to being incorporated into hierarchical semantic relations, whilst abstract nouns may reflect logical and figurative categorization because their meanings do not have subject reference and are characterized by uncertainty. Abstract nouns have been proved to build hierarchical semantic relations within their synonymic groups on certain conditions.
\end{abstract}

Key words: cognitive categorization, noun, semantic relations, synonymy, naive interpretations, native speaker's lexicon.

Citation. Belov V.A. Semantic Features of Nouns Referred to Various Lexical-and-Grammatical Categories. Vestnik Volgogradskogo gosudarstvennogo universiteta. Seriya 2. Yazykoznanie [Science Journal of Volgograd State University. Linguistics], 2020, vol. 19, no. 3, pp. 38-48. (in Russian). DOI: https://doi.org/10.15688/ jvolsu2.2020.3.4

\section{СЕМАНТИЧЕСКИЕ СВОЙСТВА ИМЕН СУЩЕСТВИТЕЛЬНЫХ РАЗЛИЧНЫХ ЛЕКСИКО-ГРАММАТИЧЕСКИХ РАЗРЯДОВ}

\author{
Вадим Алексеевич Белов \\ Череповецкий государственный университет, г. Череповец, Россия
}

\begin{abstract}
Аннотация. В статье характеризуются семантические свойства конкретных и абстрактных существительных в аспекте когнитивной категоризации. Исследование основано на результатах двух проведенных автором психолингвистических экспериментов - эксперимента по подбору синонимов и эксперимента по толкованию слов. Полученные данные верифицированы в ходе их сопоставления с данными словарей синонимов и Национального корпуса русского языка. Эксперимент по подбору синонимов показал, что испытуемые расширяют синонимические связи конкретных существительных посредством семантического сближения слов, находящихся на разных ступенях иерархии в семантическом поле. Особое внимание уделено ₹ существительным со значением лица. Их синонимические ряды, представленные в экспериментальных данных и лексикографических материалах, существенно отличаются. Эксперимент по толкованию слов показал, оै что частотным для конкретных существительных является логический (компонентный) способ толкования, а д для абстрактных - синонимический. Установлено, что конкретные существительные отражают логическую (2) категоризацию, поскольку включаются в иерархические отношения, а абстрактные существительные отра-
\end{abstract}


жают логическую и образную категоризацию, поскольку их значения не имеют предметной отнесенности и обладают неопределенностью. Выявлены условия, при которых абстрактные существительные могут включаться в иерархические отношения в пределах синонимического ряда.

Ключевые слова: когнитивная категоризация, имя существительное, семантические связи, синонимия, наивные толкования, лексикон носителя языка.

Цитирование. Белов В. А. Семантические свойства имен существительных различных лексико-грамматических разрядов // Вестник Волгоградского государственного университета. Серия 2, Языкознание. - 2020. T. 19, № 3. - C. 38-48. - DOI: https://doi.org/10.15688/jvolsu2.2020.3.4

\section{Введение}

Категориальное значение имен существительных (далее - ИС) связывается с предметностью [Есперсен, 1958; Ревзин, 1978; Щерба, 1974]. Типичное ИС представляет физически видимый и стабильный предмет [Hopper, Thompson, 1984], выделяемый в пространстве [Langacker, 1987].

Однако это категориальное значение свойственно части ИС - конкретным существительным [Стеблин-Каменский, 1974], для многих ИС характерна синкретичность, предполагающая совмещение со значениями процессуальности и признаковости [Глисон, 1959; Пешковский, 2001; Croft, 2001]. Например, такие слова, как бег, рубка, отдых, реализуют одновременно значение предметности и процессуальности. Поэтому принято считать, что ИС могут обозначать абстрактные явления физического и духовного мира, «отвлеченные понятия, которые мыслятся предметно» [Жирмунский, 1968, с. 19].

В когнитивной лингвистике различия в категориальном значении объясняются особенностями когнитивной категоризации [Langacker, 1987; Кубрякова, 2004]. Определение ИС как части речи основывается на ментальном, когнитивном выделении объекта (предмета) в деятельности, что приводит к структурированию реальности: «язык находит специальные формы разграничения структур знания по тем принципам, которые характеризуют концептуальную систему человеческого сознания и которые позволяют ей проводить категоризацию опыта» [Кубрякова, 2004, c. 251].

В настоящей работе в аспекте когнитивной категоризации изучаются не ИС в целом (гетерогенный класс единиц), а отдельные лексико-грамматические разряды ИС, обладающие общими признаками и отражающие разные способы категоризации, восприятия мира (подробнее об этом см.: [Калинина, 2007; Лакофф, 2004; Рахилина, 2008]).

С одной стороны, в основе категоризации лежит языковое осмысление явлений действительности в рамках обобщенных категорий [Болдырев, 2013; Кубрякова, 2004; Лакофф, Джонсон, 2004; Попова, Стернин, 2007; Croft, Cruse, 2004; Taylor, 2003]. Результатом категоризации становится языковая номинация предметов, которая предполагает логическое упорядочивание. Когнитивная категоризация составляет фундаментальное свойство языка: «Our ability to function in the physical and social world depends on elaborate categorization of things, processes, social relations, and other persons» [Taylor, 2003, p. 9]. С другой стороны, язык как сложный когнитивный механизм связан не только с логической, но и с нелогической (образной) составляющей сознания. Важная роль образной информации в лексиконе носителя языка отмечается в работах отечественных и зарубежных ученых (см., например: [Жинкин, 1964; Paivio, 1990]). Исходя из этого, мы толкуем категоризацию широко: существует несколько ее типов, основанных на логической и образной информации.

Цель работы - изучение семантических свойств конкретных и абстрактных ИС, являющихся результатом реализации разных типов категоризации. Как отдельная группа конкретных ИС рассмотрены существительные со значением лица. При этом учитывается, что характеристика человека может быть связана с внешними (физическими, наблюдаемыми) и внутренними (интеллектуальными, душевными) свойствами (о классификации см.: [Демина, 2004]); наименования лиц обладают «семантической двойственностью», которая обусловливает конкретность наименования и абстрактность значения: «лица всегда ассоциируются с действиями, поступками, пове- 
дением и пр. Имена лиц поэтому часто употребляются в позициях, предназначенных для событийной лексики» [Арутюнова, 2003, c. 146].

Гипотезой исследования стало предположение о том, что конкретные ИС реализуют логическую категоризацию, а абстрактные ИС способны представлять как логическую, так и образную категоризацию.

\section{Методология исследования}

Исследование основывается на результатах двух психолингвистических экспериментов - эксперимента по подбору синонимов и эксперимента по толкованию слов. Экспериментальные данные позволяют избежать субъективности [Глазанова, Штерн, 1996] и установить семантические связи слов [Лебедева, 1988].

Эксперимент по подбору синонимов относится к направленным ассоциативным экспериментам, методика которых предполагает, что ассоциации испытуемых сознательно ограничиваются [Виноградова, 2013; Выговская, 2014]. В организованном нами эксперименте реакции испытуемых были ориентированы на представление семантических (а не ассоциативных) отношений.

В эксперименте приняли участие 260 человек - студенты университета разных специальностей в возрасте от 18 до 31 года. Эксперимент проходил в три этапа с использо- ванием разных экспериментальных таблиц. Испытуемым было предложено задание: «Подобрать близкие по значению слова к словамстимулам». В качестве слов-стимулов были избраны ИС разных разрядов (табл. 1).

Полученные в ходе эксперимента данные сравнивались с данными словарей русского языка: выявлялись различия в представлении синонимических связей. В качестве основного источника использовался «Словарь синонимов русского языка» под редакцией А.П. Евгеньевой, который, по словам В.А. Козырева и В.Д. Черняк, по сей день занимает центральное место в ряду синонимических словарей [Козырев, Черняк, 2015 , с. 117], и «Словарь синонимов русского языка» под редакцией Л.Г. Бабенко.

Эксперимент по толкованию слов также является направленным ассоциативным экспериментом, однако в этом случае реакции испытуемых ограничены установкой на реакцию, которая дает возможность истолковать значение слова. Считается, что эксперимент по толкованию «позволяет проследить развитие произвольного осознания субъективного содержания значения слова» [Фрумкина, 1983, с. 48].

В эксперименте по толкованию приняли участие 166 человек - студенты университета в возрасте от 18 до 21 года. В задании анкеты испытуемых просили объяснить значение предлагаемых слов. Информация о распределении стимулов по разрядам ИС представлена в таблице 2.

Таблица 1. Распределение слов-стимулов по лексико-грамматическим разрядам (эксперимент по подбору синонимов)

Table 1. Lexico-grammatical categories of stimulus-words (experiment on the selection of synonyms)

\begin{tabular}{|l|c|}
\hline \multicolumn{1}{|c|}{ Лексико-грамматический разряд } & $\begin{array}{c}\text { Количество } \\
\text { стимулов }\end{array}$ \\
\hline Абстрактные ИС & 28 \\
\hline Конкретные ИС & 17 \\
\hline В том числе наименования лиц & 11 \\
\hline
\end{tabular}

Таблица 2. Распределение слов-стимулов по лексико-грамматическим разрядам (эксперимент на толкование слов)

Table 2. Lexico-grammatical categories of stimulus-words (experiment on the interpretation of words)

\begin{tabular}{|l|c|}
\hline \multicolumn{1}{|c|}{ Лексико-грамматический разряд } & $\begin{array}{c}\text { Количество } \\
\text { стимулов }\end{array}$ \\
\hline Абстрактные ИС & 12 \\
\hline Конкретные ИС & 16 \\
\hline В том числе наименования лиц & 4 \\
\hline
\end{tabular}


Для обработки результатов исследования и их обобщения применялись общенаучные методы индукции и дедукции, описания и количественных подсчетов, лингвистические методы словарных дефиниций, сопоставления употребления лексем в различных контекстах. Для верификации результатов использовались данные Национального корпуса русского языка (далее - НКРЯ).

\section{Результаты исследования}

Описание результатов исследования разделено на две части, представляющие обработку данных каждого эксперимента.

Обработка результатов эксперимента по подбору синонимов показала, что в среднем многочисленные синонимические связи регистрируются у конкретных и абстрактных ИС, a ограниченные синонимические связи - у наименований лиц. Причем средняя длина синонимического ряда существенно различается: если синонимический ряд конкретных ИС в среднем включает 11 слов, то ряд наименований лиц - только 4 слова.

Более того, сравнение этих показателей с материалами словарей синонимов приводит к противоречивым результатам. В «Словаре синонимов русского языка» под редакцией А.П. Евгеньевой конкретные ИС имеют ограниченные синонимические ряды, а абстрактные ИС и наименования лиц - многочисленные (табл. 3).

Таким образом, эксперимент показал, что испытуемые расширяют синонимические связи прежде всего конкретных ИС. Расширение происходит за счет создания семантической близости со словами, находящимися на разных ступенях семантической иерархии. Так, синонимический ряд с доминантой рука представлен в словарях следующими синонимами: руч$\kappa a$, лапа (разг.), лапка (разг.), длань (Евгеньева, с. 383); кисть, пясть, десница (трад.-поэт.), длань (трад.-поэт.), шуйиа (трад.-поэт.), клешня (разг., шутл.), краб (разг., шутл.), лапа (разг.) (Бабенко, с. 55). Однако испытуемые в качестве синонимов определяют гиперонимы (конечность, часть тела, тело) и гипонимы (ладонь, кисть, клешня). Для стимула лодка испытуемые выбирали реакции корабль, судно, катер, плот, илюпка, яхта, корыто; для стимула бабочка реакции насекомое, птица, моль, махаон. Все представленные реакции находятся на разных ступенях семантической иерархии. Конкретные ИС выстраиваются в иерархию внутри семантического поля, поскольку в ее основе лежит логическая таксономия предметов.

Абстрактные ИС не способны формировать такие четкие иерархические связи, что можно объяснить особенностями их категориального значения. Оно не имеет предметной отнесенности, поэтому диффузно и неопределенно. Ср.: конкретные ИС имеют четкую предметную отнесенность - носитель языка ясно представляет, чем рука отличается от пальца. Данная особенность абстрактных существительных приводит к ограниченности синонимических отношений конкретных ИС, что и отражено в ограниченных синонимических рядах, зафиксированных в словарях синонимов. В сфере абстрактных ИС некоторые понятия сложно дифференцировать. Синонимами с высокой степенью неопределенности являются слова, выражающие чувства и эмоции, например: грусть, тоска, печаль. При этом неопределенность значения способствует развитию синонимических отношений, что отражено в словарях и лексиконе носителя языка. Приведем примеры реакций, полученных в результате эксперимента, и их сопоставления с данными словарей синонимов.

Синонимический ряд с доминантой $m u$ иина: безмолвие, молчание, тишь, затишье (Евгеньева, с. 545), молчание, безмолвие (Бабенко, с. 201); испытуемые добавляют такие синонимы, как беззвучие, покой, глущь.

\section{Таблииа 3. Средняя длина синонимических рядов}

\section{Table 3. The average length of synonymic chains}

\begin{tabular}{|c|c|c|}
\hline \multirow{2}{*}{ Лексико-грамматический разряд } & \multicolumn{2}{|c|}{ Средняя длина синонимического ряда } \\
\cline { 2 - 3 } & Словарь синонимов & $\begin{array}{c}\text { Данные } \\
\text { эксперимента }\end{array}$ \\
\hline Абстрактные ИС & 3,5 & 10 \\
\hline Конкретные ИС & 2,6 & 11 \\
\hline В том числе наименования лиц & 3,5 & 4 \\
\hline
\end{tabular}




\section{РАЗВИТИЕ И ФУНКЦИОНИРОВАНИЕ РУССКОГО ЯЗЫКА}

Синонимический ряд слова привычка в двух словарях синонимов представлен следующим образом: привычка, обыкновение, обычай, манера, мода; испытуемые предлагают словарные синонимы (обычай, обыкновение) и несловарные синонимы (привязанность, пристрастие, зависимость).

Отметим, что не все полученные реакции можно считать синонимами (проблема синонимичности таких реакций рассмотрена в: [Белов, 2017]). Например, для стимула рука получены реакции конечность, тело, ладонь, которые значительно различаются с точки зрения денотативного значения, поэтому их замена в высказывании может привести к серьезному изменению смысла и ситуации высказывания:

(1) Победительница женской гонки на 5 км свободным ходом (самой стремительной за спринтами) эстонка Кристина Шмигун плакала на пьедестале не от радости, а от боли - отморозила пальцы на руках [*конечности, теле, ладони] (НКРЯ. Митьков А. Мороз по коже... // Известия. 2003. 1 авг.);

(2) Я, например, для внучки настегала своими руками [*конечностями, телом, ладонями] лоскутное одеяло, зная, что оно будет ее оберегать, давать ей энергию (НКРЯ. Народный костюм: архаика или современность? // Народное творчество. 2004);

(3) «Мам! - Сын схватил меня за руку [*конечность, тело, ладонь]. - Смотри, какие белые зубы! Как у папы!» (НКРЯ. Орлова Е. Такой же хороший, как ты // Даша. 2004).

Наименования лиц характеризуются совпадением словарных и предложенных испытуемыми синонимов: они обладают ограниченными, но стабильными синонимическими связями. Например, в словаре синонимов представлен ряд друг, товарищ, приятель, дружок (разг.); в эксперименте наиболее частотными реакциями на стимул друг стали словарные синонимы товарищ (68 реакций, $42 \%$ ), приятель (39 реакция, $24 \%$ ).

Реакции, полученные в результате эксперимента по толкованию слов, были классифицированы на основе разработанной нами типологии способов толкования. Для ее построения использовались представленные в научной литературе классификации наивных толкований (см.: [Голев, 2009; Кузнецова, 2012; Левенталь, 2014; Ростова, 2000]), а также спо- собы словарных толкований (см.: [Арбатский, 1970; Денисов, 1980; Скляревская, 2007]). Кроме того, привлекались материалы «Словаря обыденных толкований русских слов» под редакцией Н.Д. Голева. Выделено 6 способов наивного толкования на основе семантических отношений между стимулом и толкованием. Ниже представим их краткую характеристику:

1. Синонимический способ - использование синонимов для пояснения значения стимула. Такой способ отражен в реакциях $х в о р ь$, болезнь, заболевания для стимула недуг.

2. Гиперонимический способ - использование отсылки к гиперониму, к слову с более общим значением. Такой способ отражен в реакции человек на стимулы друг, приятель; в реакции желание на стимул причуда; в реакции человек на стимулы кроха, ребенок.

3. Описательный способ - использование анафорического местоимения в функции номинативного элемента. Такой способ отражен в реакции то, что едят для стимула пища; в реакции то, что суждено человеку в будущем для стимула судьба.

4. Логический (компонентный) способ использование логических операций, предполагающих компонентное выделение значения. Такой способ отражен в реакции самая горячая часть огня для стимула пламя; в реакции мелкий водоем природного происхождения для стимула родник.

5. Семантический способ - использование отсылки к семантически связанному слову, принадлежащему к одному семантическому полю, при этом реакции не относятся к синонимам, гиперонимам. Такой способ отражен в реакциях потомство, семья для стимула ребенок.

6. Ассоциативный способ - использование реакции, которая семантически не связана со стимулом. Ассоциативная связь объясняется совместной сочетаемостью стимула и реакции в речи. Примеры реализации такого способа единичны: для стимула земля дана реакция в иллюминаторе видна.

В таблице 4 представлены результаты эксперимента. Они демонстрируют основную закономерность, касающуюся распространенности способов толкования конкретных и абстрактных ИС. Для конкретных ИС наиболее 
B.A. Белов. Семантические свойства имен существительных различных лексико-грамматических разрядов

частотным способом становится логический (компонентный) способ: он представлен в 764 случаях (43 \%), у абстрактных ИС доминирует синонимический способ (383 реакции, $54 \%$ ), а логический способ представлен незначительно (83 реакции, $12 \%$ ). Среди абстрактных ИС можно выделить часть стимулов, для которых характерно толкование посредством доминанты. Так, испытуемые чаще всего толкуют стимулы недуг и хворь через отсылку к доминанте: на стимул хворь 56 реакций (93 \% от общего количества) - доминанта болезнь; 31 реакция (50\% от общего количество реакций) на стимул недуг - доминанта болезнь. К таким стимулам в эксперименте относятся вранье, фортуна, восторг.

Полученные результаты объясняются тем, что у конкретных ИС, как уже отмечалось в лингвистических работах (см., например: [Покровская, 1999; Черняк, 2010]), синонимические отношения развиты недостаточно, поэтому носителю языка сложно подобрать синоним, который адекватно передавал бы значение стимула. Абстрактные ИС обладают более неопределенным значением, что приводит, с одной стороны, к развитости их синонимических отношений, а с другой - к затруднениям при использовании логического способа толкования: для носителя языка легче подобрать синоним, чем составлять логическое толкование.

По этим же причинам синонимический способ толкования часто используется для пояснения слов - наименований лиц. Данная особенность показывает, что по семантическим свойствам наименования лиц отличаются от конкретных ИС и сближаются с абстрактными ИС.

\section{Обсуждение результатов}

Обнаруженные в результате двух экспериментов особенности конкретных и абстрактных имен существительных являются выражением общих принципов их когнитивной организации. Семантические особенности конкретных и абстрактных ИС отражают разные типы категоризации.

Конкретные ИС выстраивают иерархические отношения, основанные на таксономической классификации предметов действительности. Данный тип категоризации можно назвать логической. Она приводит, во-первых, к расширению синонимических рядов за счет гиперонимов и гипонимов, а во-вторых, к распространению логического способа толкования. Таким образом, конкретное ИС всегда оказывается в системе единиц, находящихся на разных ступенях семантической иерархии. По словам Ю. Найды, логическая (компонентная) категоризация предполагает вертикальный анализ семантических единиц, то есть обращение к понятию более высокого ранга и последующее выявление отличительных и общих признаков [Найда, 1983].

При этом наименования лиц представляют собой отдельную категорию: они не обладают семантическими свойствами, связанными с реализацией логической категоризации. На семантико-когнитивную организацию наименований лиц в большей мере влияет нелогическое (образное) восприятие.

Абстрактные ИС не выстраивают четких иерархических отношений. Расширение синонимических связей происходит на основе нелогических принципов. Логическая категоризация для абстрактных ИС затруднена из-за

\section{Таблииа 4. Реализация способов толкования слов в эксперименте}

\section{Table 4. Ways of interpreting words in an experiment}

\begin{tabular}{|c|c|c|c|c|c|c|c|c|}
\hline \multirow{3}{*}{ Способ толкования } & \multicolumn{6}{|c|}{ Разряды ИС } & \multirow{2}{*}{\multicolumn{2}{|c|}{ Всего }} \\
\hline & \multicolumn{2}{|c|}{ Абстрактные } & \multicolumn{2}{|c|}{ Конкретные } & \multicolumn{2}{|c|}{ Наименования лиц } & & \\
\hline & $\begin{array}{l}\text { Кол-во } \\
\text { реакций }\end{array}$ & $\%$ & $\begin{array}{c}\text { Кол-во } \\
\text { реакций }\end{array}$ & $\%$ & $\begin{array}{c}\text { Кол-во } \\
\text { реакций }\end{array}$ & $\%$ & $\begin{array}{l}\text { Кол-во } \\
\text { реакций }\end{array}$ & $\%$ \\
\hline Синонимический & 383 & 54 & 408 & 22 & 115 & 41 & 906 & 33 \\
\hline Гиперонимический & 115 & 16 & 290 & 16 & 123 & 44 & 528 & 19 \\
\hline Описательный & 101 & 14 & 104 & 6 & 6 & 2 & 211 & 8 \\
\hline Логический & 83 & 12 & 764 & 43 & 20 & 7 & 867 & 31 \\
\hline Семантический & 5 & 1 & 131 & 8 & 8 & 3 & 144 & 5 \\
\hline Ассоциативный & 15 & 2 & 64 & 4 & 8 & 3 & 87 & 3 \\
\hline Отказ от толкования & 5 & 1 & 21 & 1 & 0 & 0 & 26 & 1 \\
\hline Итого & 707 & 100 & 1782 & 100 & 280 & 100 & 2769 & 100 \\
\hline
\end{tabular}




\section{РАЗВИТИЕ И ФУНКЦИОНИРОВАНИЕ РУССКОГО ЯЗЫКА}

неопределенности значения, которая делает невозможным четкую логическую таксономию. Такая категоризация нами названа образной.

Итак, для прототипических (наиболее типичных) случаев характерна реализация логической категоризации для конкретных ИС и реализация логической и образной категоризации для абстрактных ИС. Однако в лексиконе возможны переходные и сложные синонимические ряды и для конкретных, и для абстрактных ИС.

Конкретные ИС, как показывает С. Ульманн, могут утрачивать логическую категоризацию по причине отсутствия четких границ между вещами, недостаточной осведомленности носителей языка об этих вещах [Ullmann, 1967]. Например, в синонимическом ряду метель, метелица, вьюга, пурга, буран члены ряда нечетко дифференцируются в речевых употреблениях и словарных описаниях. В НКРЯ обнаруживается большое количество примеров совместных употреблений синонимов, когда говорящий не может точно определить, какое природное явление наблюдает (см. пример 4). Встречаются неединичные примеры создания сложной номинации метель-вьюга (вьюга-метель), что связано с трудностями дифференциации понятий (см. пример 5), а также наблюдаются случаи взаимозаменяемости слов в тексте (см. пример 6):

(4) Жестоко мерзли казаки и их лошади на постах в зимнюю стужу, во время вьюги и метели (НКРЯ. Краснов П. Н. Атаманская памятка. 1898);

(5) И когда над лесной сторожкой волчьим воем поет, надрывается метель-вьюга или трещит, лютует в бору мороз, мы с лесником Демьяном долго беседуем, включив радиоприемник, слушаем последние известия и только потом ложимся в постель (НКРЯ. Вести с опушки // Юный натуралист. 1975);

(6) За окном была вьюга, сквозь которую я увидел, что через метель пробивается автомобиль (НКРЯ. Шульгин В. В. [Разрозненные воспоминания]. 1967-1974).

Данный ряд можно отнести к нецентрированным рядам, свойствами которых является отсутствие доминанты и иерархической семантической организации (подробнее о таких рядах см.: [Белов, 2016]).
К нарушению логической категоризации может привести нераспространенность предметов в современной жизни. Так, в наивной картине мира дифференциация между словами родник и источник не прослеживается, хотя в научной картине мира понятия различаются (слово источник является гиперонимом для слов родник и ключ). Нечеткая дифференциация слов допускает замены слов в контекстах:

(7) Табличка при источнике [*роднике] гласит: «Родник [*источник] - это бесценный дар природы (НКРЯ. Соколова К., Олейник Т. Полная опись московских родников // Столица. 1997. 1 июля).

Некоторые абстрактные ИС могут включаться в иерархические отношения, о чем свидетельствует частотное использование семантического толкования посредством доминанты синонимического ряда. Упорядоченность в таком случае оказывается размытой в силу неопределенности категориального значения. Поэтому можно говорить о том, что абстрактные ИС, обладая широким значением, способны выражать логическую категоризацию, но только в определенных случаях и в пределах синонимического ряда.

\section{Заключение}

Обращение к экспериментальным и корпусным данным позволило выявить реализацию разных типов категоризации разрядов ИС, обусловливающих их семантические свойства. Выдвинутая в нашей работе гипотеза о том, что конкретным ИС свойственна реализация логической категоризации, а абстрактные ИС способны представлять логическую и образную категоризацию, в целом подтвердилась. Однако в лексиконе носителя языка отмечаются сложные, нетипичные случаи.

\section{СПИСОК ЛИТЕРАТУРЫ}

Арбатский Д. И., 1970. Основные способы толкования значения слов // Русский язык. № 3. С. 26-31.

Арутюнова Н. Д., 2003. Предложение и его смысл (логико-семантические проблемы). М. : УРСС. $384 \mathrm{c}$.

Белов В. А., 2016. Об иерархическом и неиерархическом строении синонимических рядов 
// Вестник Воронежского государственного университета. Серия: Лингвистика и межкультурная коммуникация. № 1. С. 5-10.

Белов В. А., 2017. Синонимические отношения в языке и высказывании // Вестник Новосибирского государственного педагогического университета. Т. 7, № 6. С. 263-280.

Болдырев Н. Н., 2013. Актуальные задачи когнитивной лингвистики на современном этапе // Вопросы когнитивной лингвистики. № 1 (034). C. 5-13.

Виноградова О. Е., 2013. Направленный ассоциативный эксперимент в описании семантики слова // Известия Российского государственного педагогического университета им. А.И. Герцена. № 161. С. 67-73.

Выговская Д. Г., 2014. Ассоциативный эксперимент как один из методов в психолингвистике // Наука Южно-Уральского государственного университета : материалы 66-й науч. конф. (Челябинск, 15-17 апр. 2014 г.). Челябинск : ЮУрГУ. С. 1157-1164.

Глазанова Е. В., Штерн А. С., 1996. Градуальное измерение вербальной лексики // Проблемы современного теоретического и синхронноописательного языкознания. Вып. 4. Семантика и коммуникация / под ред. Л. В. Сахарного. СПб. : СПбГУ. С. 177-189.

Глисон Г., 1959. Введение в дескриптивную лингвистику. М. : Изд-во иностр. лит. 486 с.

Голев Н. Д., 2009. Обыденное метаязыковое сознание как онтологический и гносеологический феномен (к поискам «лингвогносеологем») // Обыденное метаязыковое сознание: онтологические и гносеологические аспекты Ч. 1 : коллектив. моногр. / отв. ред. Н. Д. Голев. Кемерово ; Барнаул : Изд-во Алт. ун-та. С. 7-41.

Демина Е. И., 2004. Новые наименования лиц в современном русском языке : дис. ... канд. филол. наук. Самара. 229 с.

Денисов П. Н., 1980. Лексика русского языка и принципы ее описания. М. : Рус. яз. 253 с.

Есперсен О., 1958. Философия грамматики. М. : Изд-во иностр. лит. $407 \mathrm{c.}$

Жинкин Н. И., 1964. О кодовых переходах во внутренней речи // Вопросы языкознания. № 6. C. $26-38$.

Жирмунский В. М., 1968. О природе частей речи и их классификации // Вопросы теории частей речи : На материале языков различных типов : сб. ст. / отв. ред. В. М. Жирмунский, О. П. Суник. Л. : Наука. С. 7-32.

Калинина Л. В., 2007. К вопросу о критериях выделения и отличительных приметах лексико-грамматических разрядов имен существительных // Вопросы языкознания. № 3. С. 55-70.
Козырев В. А., Черняк В. Д., 2015. Лексикография русского языка: век нынешний и век минувший. 2-е изд., испр. и доп. СПб. : Изд-во РГПУ им. А.И. Герцена. 631 с.

Кубрякова Е. С., 2004. Язык и знание. На пути получения знаний о языке: части речи с когнитивной точки зрения. Роль языка в познании мира. М. : Яз. слав. культуры. 560 с.

Кузнецова Т. Ю., 2012. Стратегии семантизации слов носителями русского языка (экспериментальное исследование вариативности толкований) : автореф. дис. ... канд. филол. наук. Кемерово. 28 с.

Лакофф Д., 2004. Женщины, огонь и опасные вещи. Что категории языка говорят нам о мышлении. М. : Яз. слав. культуры. 792 с.

Лакофф Дж., Джонсон М., 2004. Метафоры, которыми мы живем. M. : URSS. 256 с.

Лебедева С. В., 1988. Два подхода к исследованию лексической синонимии // Психолингвистические исследования значения слова и понимания текста : межвуз. темат. сб. науч. тр. Калинин : КГУ. С. 68-73.

Левенталь И. В., 2014. Лингвистическая типология слов в одноязычном учебном словаре русского языка для иностранцев : дис. ... канд. филол. наук. СПб. 256 с.

Найда Ю. А., 1983. Процедуры анализа компонентной структуры референционного значения // Новое в зарубежной лингвистике. Вып. 14. Проблемы и методы лексикографии / общ. ред. и вступ. ст. Б. Ю. Городецкого. М. : Прогресс. С. 61-74.

Пешковский А. М., 2001. Русский синтаксис в научном освещении. М. : Яз. слав. культуры. 510 с.

Покровская Е. А. 1999. Лексическая синонимия в квантитативно-системном аспекте (на материале русского языка) : дис. ... канд. филол. наук. М. 170 c.

Попова З. Д., Стернин И. А., 2007. Когнитивная лингвистика. М. : АСТ : Восток-Запад. 314 с.

Рахилина Е. В., 2008. Когнитивный анализ предметных имен: семантика и сочетаемость. М. : Рус. слов. $416 \mathrm{c}$

Ревзин И. И., 1978. Структура языка как моделирующей системы. М. : Наука. 287 с.

Ростова А. Н., 2000. Метатекст как форма экспликации метаязыкового сознания : (На материале русских говоров Сибири). Томск : Изд-во Том. ун-та. $193 \mathrm{c.}$

Скляревская Г. Н., 2007. «Нормативный толковый словарь живого русского языка»: основные постулаты и типологические признаки // Нормативный толковый словарь живого русского языка: теоретические проблемы и практические трудности : сб. ст. / под ред. Г. Н. Скляревской. СПб. : Филол. фак. СПбГУ. С. 17-41. 
Стеблин-Каменский М. И., 1974. Спорное в языкознании. Л. : Изд-во Ленингр. ун-та. 142 с.

Фрумкина Р. М., 1983. Психолингвистические методы изучения семантики // Психолингвистические проблемы семантики / отв. ред. А. А. Леонтьев, А. М. Шахнарович. М. : Наука. С. 46-85.

Черняк В. Д., 2010. Синонимия в русском языке. М. : Академия. $128 \mathrm{c}$.

Щерба Л. В., 1974. Языковая система и речевая деятельность. Л. : Наука. 428 с.

Croft W., 2001. Radical Construction Grammar. Syntactic Theory in Typological Perspective. Oxford: Oxford University Press. 417 p.

Croft W., Cruse A., 2004. Cognitive Linguistics. Cambridge : Cambridge University Press. 237 p.

Hopper P., Thompson S., 1984. The Discourse Basis for Lexical Categories in Universal Grammar // Language. Vol. 60, № 4. P. 703-752.

Langacker R., 1987. Noun and Verb // Language. Vol. 63, № 1. P. 53-94.

Paivio A., 1990. Mental Representations: A Dual Coding Approach. Oxford : Oxford University Press. 322 p.

Taylor J. R., 2003. Cognitive Grammar. Oxford : Oxford University Press. $621 \mathrm{p}$.

Ullmann S., 1967. Semantics: An Introduction to the Science of Meaning, Oxford: Basil Blackwell. 278 p.

\section{ИСТОЧНИКИ И СЛОВАРИ}

Бабенко - Словарь синонимов русского языка : более 5000 синонимических рядов : ок. 30000 словсинонимов / под общей ред. проф. Л. Г. Бабенко. М. : АСТ : Астрель, 2011. 829 с.

Евгеньева - Словарь синонимов русского языка. В 2 т. / под ред. А. П. Евгеньевой. М. : Астрель : АСТ, 2003. Т. 1.680 с.; Т. 2.856 с.

НКРЯ - Национальный корпус русского языка. URL: http://www.ruscorpora.ru.

Словарь обыденных толкований русских слов : Лексика природы. В 2 т. Т. 1. А-М (АБРИКОС - МУРАВЕЙ) (478 слов-стимулов) / под ред. Н. Д. Голева. Кемерово : Изд-во Кемер. ун-та, 2011. 500 с.

\section{REFERENCES}

Arbatskiy D. I., 1970. Osnovnye sposoby tolkovaniya znacheniya slov [The Main Ways of Interpreting the Meaning of Words]. Russkiy yazyk, no. 3, pp. 26-31.

Arutyunova N.D., 2003. Predlozhenie i ego smysl (logiko-semanticheskie problemy) [The Sentence and Its Meaning (Logical and Semantic Problems)]. Moscow, URSS Publ. 384 p.
Belov V.A, 2016. Ob ierarkhicheskom i neierarkhicheskom stroenii sinonimicheskikh ryadov [On Hierarchic and Non-Hierarchic Structure of Synonymic Chains]. Vestnik Voronezhskogo gosudarstvennogo universiteta. Seriya: Lingvistika i mezhkulturnaya kommunikatsiya [Proceedings of Voronezh State University. Series: Linguistics and Intercultural Communication], no. 1, pp. 5-10.

Belov V.A, 2017. Sinonimicheskie otnosheniya v yazyke i vyskazyvanii [Synonymic Relations in Language and Utterance]. Vestnik Novosibirskogo gosudarstvennogo pedagogicheskogo universiteta [Novosibirsk State Pedagogical University Bulletin], vol. 7, no. 6, pp. 263-280.

Boldyrev N.N., 2013. Aktualnye zadachi kognitivnoy lingvistiki na sovremennom etape [On the Integrative Theory of Linguistic Representation of Knowledge]. Voprosy kognitivnoy lingvistiki [Issues of Cognitive Linguistics], no. 1 (034), pp. 5-13.

Vinogradova O.E., 2013. Napravlennyy assotsiativnyy eksperiment v opisanii semantiki slova [Directed Associative Experiment for Describing Word Semantics]. Izvestiya Rossiyskogo gosudarstvennogo pedagogicheskogo universiteta im. A.I. Gertsena [Izvestia: Herzen University Journal of Humanities \& Sciences], no. 161, pp. 67-73.

Vygovskaya D. G., 2014. Assotsiativnyy eksperiment kak odin iz metodov $\mathrm{v}$ psikholingvistike [Associative Experiment as One of the Methods in Psycholinguistics]. Nauka Yuzhno-uralskogo gosudarstvennogo universiteta: Materialy 66$y$ nauch. konf. (Chelyabinsk, 15-17 apr. 2014 g.). Chelyabinsk, YuUrGU, pp. 1157-1164.

Glazanova E.V., Shtern A.S., 1996. Gradualnoe izmerenie verbalnoy leksiki [Gradual Dimension of Verbal Vocabulary]. Sakharnyy L.V., ed. Problemy sovremennogo teoreticheskogo i sinkhronnoopisatelnogo yazykoznaniya. Vyp. 4 Semantika i kommunikatsiya [Problems of Modern Theoretical and Synchronous-Descriptive Linguistics. Issue 4. Semantics and Communication]. Saint Petersburg, SPbGU, pp. 177-189.

Glison G., 1959. Vvedenie v deskriptivnuyu lingvistiku [Introduction to Descriptive Linguistics], Moscow, Izd-vo inostrannoy literatury, $486 \mathrm{p}$.

Golev N.D., 2009. Obydennoe metayazykovoe soznanie kak ontologicheskiy i gnoseologicheskiy fenomen (k poiskam «lingvognoseologem») [Ordinary Metalinguistic Consciousness as an Ontological and Epistemological Phenomenon (To the Search for "Linguo-Epistemological Units")]. Golev N.D., ed. Obydennoe metayazykovoe soznanie: ontologicheskie i gnoseologicheskie aspekty. 
Ch. 1: kollektiv. monogr. [Ordinary Metalanguage Consciousness: Ontological and Epistemological Aspects. Part 1. Collective Monograph]. Kemerovo, Barnaul, Izd-voAltayskogo universiteta, pp. 7-41.

Demina E.I., 2004. Novye naimenovaniya lits $v$ sovremennom russkom yazyke: dis. ... kand. filol. nauk [New Names of Persons in Modern Russian. Cand. philol. sci. diss]. Samara. 229 p.

Denisov P. N., 1980. Leksika russkogo yazyka $i$ printsipy ee opisaniya [Russian vocabulary and principles of its description]. Moscow, Russkiy yazyk Publ. 253 p.

Jespersen O., 1958. Filosofiya grammatiki [The Philosophy of Grammar]. Moscow, Izd-vo inostrannoy literatury. $407 \mathrm{p}$.

Zhinkin N.I., 1964. O kodovykh perekhodakh vo vnutrenney rechi [About Code Transitions in Internal Speech]. Voprosy yazykoznaniya [Topics in the Study of Language], no. 6, pp. 26-38.

Zhirmunskiy V.M., 1968. O prirode chastey rechi i ikh klassifikatsii [On the Nature of Parts of Speech and Their Classification]. Zhirmunskiy V.M., Sunik O.P., eds. Voprosy teorii chastey rechi: Na materiale yazykov razlichnykh tipov: sb. st. [Issues of the Theory of Parts of Speech. Based on Languages of Various Types.Collected Articles]. Leningrad, Nauka Publ., pp. 7-32.

Kalinina L.V., 2007. K voprosu o kriteriyakh vydeleniya i otlichitelnykh primetakh leksiko-grammaticheskikh razryadov imen sushchestvitelnykh [On the Criteria of Determining Lexico-Grammatical Classes of Nouns and Their Distinguishing Marks]. Voprosy yazykoznaniya [Topics in the Study of Language], no. 3, pp. 55-70.

Kozyrev V.A., Chernyak V.D., 2015. Leksikografiya russkogo yazyka: vek nyneshniy $i$ vek minuvshiy [Russian Lexicography: Present Century and Past Century]. Saint Petersburg, Izd-vo RGPU im. A.I. Gertsena. 631 p.

Kubryakova E.S., 2004. Yazyk $i$ znanie. Na puti polucheniya znaniy o yazyke: chasti rechi s kognitivnoy tochki zreniya. Rol yazyka $v$ poznanii mira [Language and Knowledge. On the Way to Gaining Knowledge About the Language: Parts of Speech from a Cognitive Point of View. The Role of Language in the Knowledge of the World]. Moscow, Yazyki slavyanskoy kultury Publ. 560 p.

Kuznetsova, T. YU., 2012. Strategii semantizatsii slov nositelyami russkogo yazyka (eksperimentalnoe issledovanie variativnosti tolkovaniy): avtoref. dis. ... kand. filol. nauk [Strategies for the Semantization of Words by Speakers of the Russian Language (An Experimental Study of the Variability of Interpretations). Cand. philol. sci. abs. diss.]. Kemerovo. 28 p.
LakoffG., 2004. Zhenshchiny, ogon i opasnye veshchi. Chto kategorii yazyka govoryat nam o myshlenii [Women, Fire and Dangerous Things. What Categories of Language Tell Us About Thinking]. Moscow, Yazyki slavyanskoy kultury Publ. 792 p.

Lakoff G., Johnson M., 2004 Metafory, kotorymi my zhivem [Metaphors We Live By]. Moscow, URSS. 256 p.

Lebedeva S.V., 1988. Dva podkhoda k issledovaniyu leksicheskoysinonimii [TwoApproaches to the Study of Lexical Synonymy]. Psikholingvisticheskie issledovaniya znacheniya slova $i$ ponimaniya teksta: mezhvuz. temat. sb. nauch. tr. [Psycholinguistic Studies of Word Meaning and Text Understanding. Interuniversity Thematic Collection of Scientific Papers]. Kalinin, KGU, pp. 68-73.

Levental I.V., 2014. Lingvisticheskaya tipologiya slov vodnoyazychnom uchebnom slovare russkogo yazyka dlya inostrantsev: dis. ... kand. filol. nauk [Linguistic Typology of Words in the Monolingual Educational Dictionary of the Russian Language for Foreigners. Cand. philol. sci. diss.]. Saint Petersburg. 256 p.

Nayda Y.A., 1983. Protsedury analiza komponentnoy struktury referentsionnogo znacheniya [Procedures for Analyzing the Component Structure of the Reference Value]. Novoe $v$ zarubezhnoy lingvistike. Vyp. 14. Problemy $i$ metody leksikografii [New in Foreign Linguistics. Iss. 14. Problems and Methods of Lexicography]. Moscow, Progress Publ., pp. 61-74.

Peshkovskiy A.M., 2001. Russkiy sintaksis v nauchnom osveshchenii [Russian Syntax in Scientific Coverage]. Moscow, Yazyki slavyanskoy kultury Publ. 510 p.

Pokrovskaya E.A., 1999. Leksicheskaya sinonimiya $v$ kvantitativno-sistemnom aspekte (na materiale russkogo yazyka): dis. ... kand. filol. nauk [Lexical Synonymy in the Quantitative-Systemic Aspect (Based on the Material of the Russian Language). Cand. philol. sci. diss.]. Moscow. 170 p.

Popova Z.D., Sternin I.A., 2007. Kognitivnaya lingvistika [Cognitive Linguistics]. Moscow, AST Publ., Vostok-Zapad Publ. 314 p.

Rakhilina E.V., 2008. Kognitivnyy analiz predmetnykh imen: semantika $i$ sochetaemost [Cognitive Analysis of Subject Names: Semantics and Compatibility]. Moscow, Russkie slovari Publ. $416 \mathrm{p}$.

Revzin I.I., 1978. Struktura yazyka kak modeliruyushchey sistemy [The Structure of the Language as a Modeling System]. Moscow, Nauka Publ. 287 p.

Rostova A.N., 2000. Metatekst kak forma eksplikatsii metayazykovogo soznaniya: (Na materiale 
russkikh govorov Sibiri) [Metatext as a Form of Explication of Metalanguage Consciousness: (On the Material of the Russian Dialects of Siberia)]. Tomsk, Izd-vo Tomskogo universiteta. $193 \mathrm{p}$.

Sklyarevskaya G.N., 2007. «Normativnyy tolkovyy slovar zhivogo russkogo yazyka»: osnovnye postulaty i tipologicheskie priznaki ["Regulatory Explanatory Dictionary of the Living Russian Language": Basic Postulates and Typological Signs]. Normativnyy tolkovyy slovar zhivogo russkogo yazyka: teoreticheskie problemy $i$ prakticheskie trudnosti: sb. st. [Normative Explanatory Dictionary of the Living Russian Language: Theoretical Problems and Practical Difficulties. Collected Articles]. Saint Petersburg, Filologicheskiy fakultet SPbGU, pp. 17-41.

Steblin-Kamenskiy M.I., 1974. Spornoe v yazykoznanii [Controversial in Linguistics], Leningrad, Izdvo Leningradskogo universiteta. $142 \mathrm{p}$.

Frumkina R.M., 1983. Psikholingvisticheskie metody izucheniya semantiki [Psycholinguistic Methods of Studying Semantics]. Psikholingvisticheskie problemy semantiki [Psycholinguistic Issues of Semantics]. Moscow, Nauka Publ., pp. 46-85.

Chernyak V.D., 2010. Sinonimiya v russkom yazyke [Synonymy in Russian]. Moscow, Akademiya Publ. 128 p.

Shcherba L.V., 1974. Yazykovaya sistema i rechevaya deyatelnost [Language System and Speech Activity]. Leningrad, Nauka Publ. $428 \mathrm{p}$.

Croft W., 2001.Radical Construction Grammar. Syntactic Theory in Typological Perspective. Oxford, Oxford University Press. $417 \mathrm{p}$.

Croft W., Cruse A., 2004. Cognitive Linguistics. Cambridge, Cambridge University Press. 237 p.
Hopper P., Thompson S., 1984.The Discourse Basis for Lexical Categories in Universal Grammar. Language, vol. 60, no. 4, pp. 703-752.

Langacker R., 1987. Noun and Verb. Language, vol. 63, no. 1, pp. 53-94.

Paivio A., 1990. Mental Representations: A Dual Coding Approach. Oxford, Oxford University Press. $322 \mathrm{p}$.

Taylor J., 2003. Cognitive Grammar. Oxford, Oxford University Press. $621 \mathrm{p}$.

Ullmann S., 1967. Semantics: An Introduction to the Science of Meaning. Oxford, Basil Blackwell. $278 \mathrm{p}$.

\section{SOURCES AND DICTIONARIES}

Babenko L.G., ed. Slovar sinonimov russkogo yazyka: bolee 5000 sinonimicheskikh ryadov: ok. 30000 slov-sinonimov [Dictionary of Synonyms of the Russian Language. More than 5000 Synonymic Chains. About 30,000 Words-Synonyms]. Moscow, AST Publ., Astrel Publ., 2011. 829 p.

Evgenyeva A.P., ed. Slovar sinonimov russkogo yazyka. $V 2 t$. [Dictionary of Synonyms of the Russian Language. In 2 Vols]. Moscow, Astrel Publ., AST Publ., 2003, vol. 1. 680 p.; vol. 2. 856 p.

Natsionalnyy korpus russkogo yazyka [National Corpus of the Russian Language]. URL: http:// www.ruscorpora.ru.

Golev N.D., ed. Slovar obydennykh tolkovaniy russkikh slov: Leksika prirody. V2 t. T. 1. A-M (ABRIKOSMURAVEY) (478 slov-stimulov) [Dictionary of Native Interpretations of Russian Words: Nature's Vocabulary. In 2 Vols. Vol. 1. A-M (APRICOT-ANT)]. Kemerovo, Izd-vo Kemerovskogo universiteta, $2011.500 \mathrm{p}$.

\section{Information About the Author}

Vadim A. Belov, Candidate of Sciences (Philology), Associate Professor, Department of German Philology and International Communication, Cherepovets State University, Prosp. Lunacharskogo, 5, 162600 Cherepovets, Russia, belov.vadim.a@gmail.com, https://orcid.org/0000-0002-4173-2000

\section{Информация об авторе}

Вадим Алексеевич Белов, кандидат филологических наук, доцент кафедры германской филологии и межкультурной коммуникации, Череповецкий государственный университет, просп. Луначарского, 5, 162600 г. Череповец, Россия, belov.vadim.a@gmail.com, https://orcid.org/0000-0002-4173-2000 